\title{
PRODUCTIVITY AND COSTS OF TIMBER EXTRACTION BY URUS MIII SKYLINE YARDER IN NORTHEAST TURKEY
}

\section{PRODUKTIVNOST I TROŠKOVI IZNOŠENJA DRVA POMOĆU URUS MIII ŽIČCRA U SJEVEROISTOČNOJ TURSKOJ}

\author{
Tolga OZTURK', Necmettin SENTURK'1
}

\begin{abstract}
Summary
The purpose of this study is to investigate the productivity and cost of the Urus MIII skyline yarder during extraction of timber from spruce stands in northeast Turkey. The productivity of Urus MIII skyline yarder was determined by using the methods of work and time study. The research results implies that some working characteristics of the Urus MIII skyline yarder such as fuel consumption, load volume, yarding distance, speed of the carriage, time consumption per phases have an important impact on productivity of the skyline yarder. The results indicated that the productivity of Urus MIII skyline yarder was $10.63 \mathrm{~m}^{3} / \mathrm{hr}$ for average $253 \mathrm{~m}$. Daily productivity was found $84.80 \mathrm{~m}^{3}$. The unit cost of yarder was found to be $30.00 € / \mathrm{hr}$. Also, the average fuel consumption was $5 \mathrm{liter} / \mathrm{hr}$.
\end{abstract}

KEY WORDS: Urus MII skyline yarder, timber extraction, spruce, productivity

\section{INTRODUCTION}

\section{UVOD}

Cable yarding operations continue to be an important technique for harvesting timber. It is proven to be low impact on both soil and the residual stand, and suitable for steep terrain (Stampfer et al., 2006). Efficient harvesting in steep terrain is usually linked to cable based harvesting system (Huber and Stampfer, 2015) and their use in the mountainous regions of Europe is becoming more widespread (Proto and Zimbalatti, 2015). In the light of increased global competition, which is imposing a growing strain on all commercial activities, including wood harvesting, forest operations must increase their productivity, while decreasing production costs (Hoesch, 2003). Cable extraction in forest stands is a desirable alternative to either a skidder or forwarder on a sensitive site (Visser and Stampfer, 1998; Melemez and Tunay, 2014) and erosional region (Ozturk,
2004). Besides, cable yarding can be implemented in any weather conditions and result in less damaging to the forest ecosystem than tractor skidding in harvesting area (Eroglu et al., 2009). Timber harvesting is still one of the most important forestry activities. Timber harvesting is still one of the most important forestry activities in Eastern Black Sea Region skyline yarders are mostly used for timber extraction. The average land slope of this generally forest region is above $60 \%$. The forest structure of Eastern Black Sea region is one from the richest forest regions of Turkey. This region is a mountainous area and road density is lowest according to another forestry area in country. The road density is changed between 11 and $16 \mathrm{~m} /$ ha (Ozturk, 2004). Enhancement of forest infrastructure is prerequisite for entire wood value added chain and should consider a prior through qualitative and quantitative assessment of the existing road networks (Enache et al., 2015). 


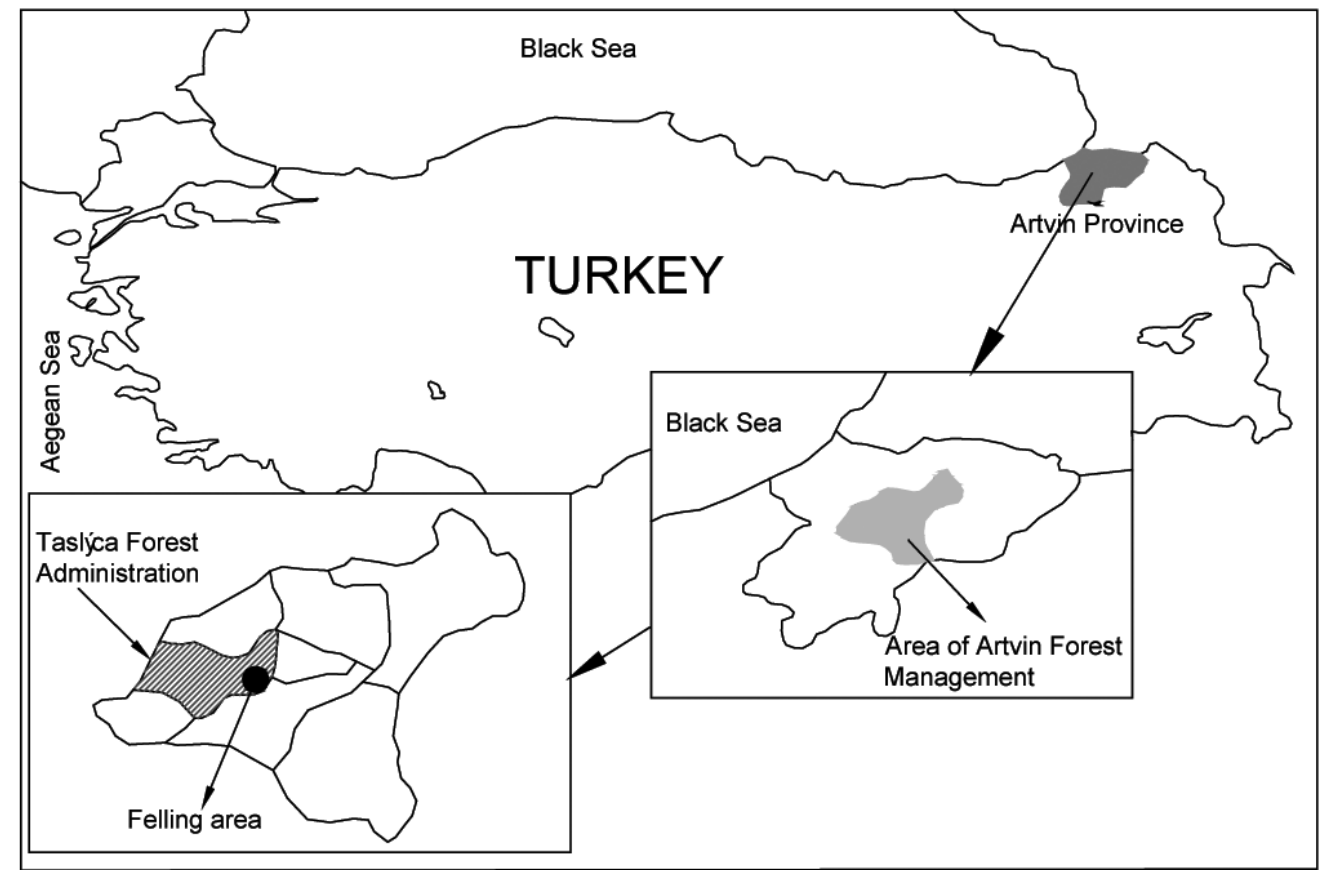

Figure 1. Study area

Slika 1. Područje istraživanja

The extraction of forest products is very difficult, expensive and time-consuming operation (Zimbalatti and Proto, 2010). Timber transportation is divided into two stages in Turkey. These are primary transportation and secondary transportation. Ground based timber extraction is done by skidders and adopted farm tractors, while in steep terrain cable systems Koller K300, Gantner and Urus MIII are usually in use (Ozturk and Senturk, 2006).

The aim of this study was to perform a time study to determine the productivity of Urus MIII skyline yarder in extraction of timber from spruce forests. The productivity of Urus MIII skyline yarder was investigated in harvesting area. Also, the hourly cost of Urus MIII skyline yarder was determined. The mounting and dismounting times were investigated according to terrain conditions such as ground slope, vegetation cover, and the shapes of terrain. The structure of total consumed time, time standards of work cycles and daily output standards for yarding distances were established.

\section{MATERIAL AND METHODS MATERIJALI I METODE}

\section{Study Area - Područje istraživanja}

The study area is managed by Taslica Forest Office within the Artvin Forest Administration (Fig. 1). The total size of Taslica Forest Office is 15600 ha and road density is approximately $16 \mathrm{~m} / \mathrm{ha}$. The most important commercial tree species are Picea orientalis (L.) Link., Abies nordma$n n i a n a$ (Steven.) Spach., Fagus orientalis (Lipsky.) and Pinus sylvestris (L.). The research was conducted at compar- tments 33 and 34 . The soil type of this region is loam. The average slope of harvesting area is between 60 and $75 \%$. The yarder with a 400 meters line length was installed and for this work, an operator and three additional workers. A corridor for skyline yarder operation was 2.5 meters wide. The intermediate supports were not used along the yarding line length. Lateral dragging during the yarder operations varied between 5 and 23 meters. Timber yarding operations were carried out uphill. In harvesting area, all trees were felled and delimbed motor-manually with a chainsaw. The length of timber yarding was changed between 4 and 6 meters and the diameter of timber was between 28 and $62 \mathrm{~cm}$.

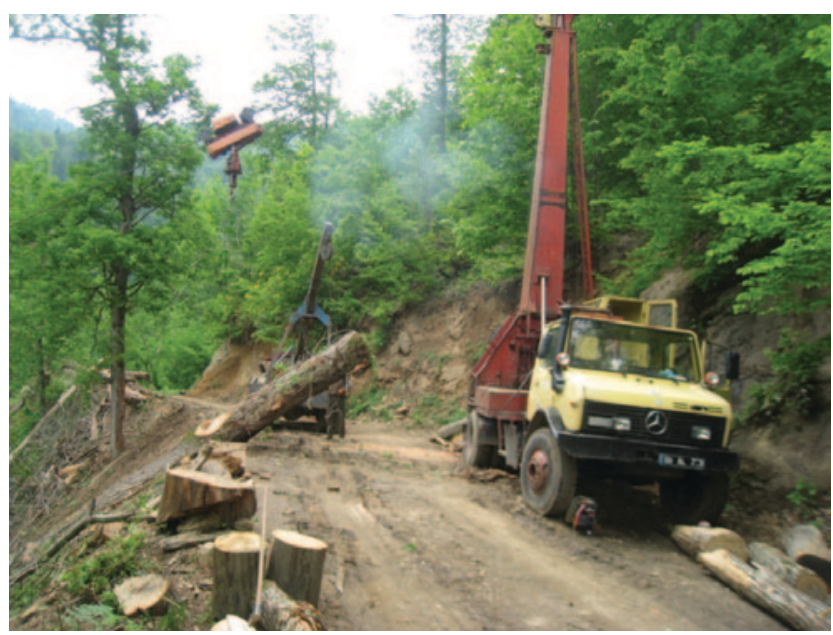

Figure 2. Urus MIII skyline yarder Slika 2. Urus MIII žičara 
Tablo 1. Technical features of Urus MIII skyline yarder

Tablica 1. Tehničke karakteristike žičare Urus MIII

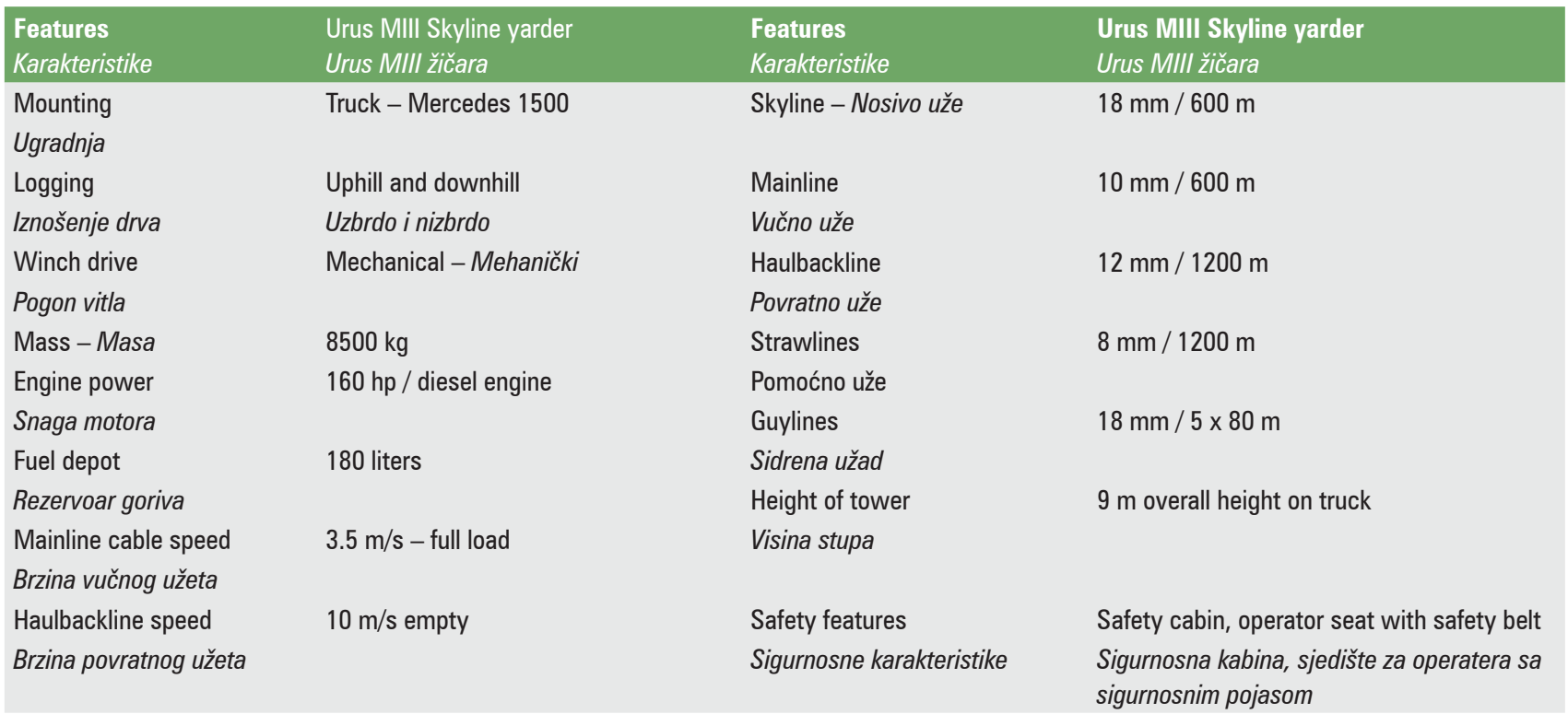

\section{Technical Features of Urus MIII Skyline Yarder - Tehničke karakteristike žičare Urus MIII}

Urus MIII skyline yarder is in use in Turkey since 1980's (Fig. 2). The maximum extraction distance of Urus MIII skyline yarder is 600 meters and four workers are employed for operating the skyline yarder. The mounting time of the skyline yarder is between $4-8$ hours, while the dismantling time is between 4-6 hours depending on terrain conditions and installation distance. The technical features of the Urus MIII skyline yarder is showed in Table 1.

\section{Variables and Data Collection - Varijable i prikupljanje podataka}

Time study is a set of procedures for determining the amount of time required, under certain standard conditions of measurement, for tasks involving some human, machine or combined activity (Wang et al., 2003). Time study is an important research tool used in comparing productivity at forest harvesting systems across varying conditions (McDonald and Fulton, 2005). Also, the productivity analysis of cable extraction is an important factor for road network planning (Cavalli and Grigolato, 2010). Time measurement studies were conducted in several different studies for forest machines. Also, for productivity of using forest machines are used different time measurement techniques (Aykut et al., 1997; Caglar et al., 2003; Ozturk, 2004).

The repetition time study method was used to determining the production of Urus MIII skyline yarder. Time consumption is conducted using the repetition-timing method to determine the total yarding cycles times (Proto and Zimbalatti, 2015). The time elements considered in the yarding work cycles include; travel of unloaded carriage, hooking of load, travel of loaded carriage and unhooking of load. During the use of skyline yarder, recorded data included productivity cycle time elements and other independent variables associated with each activity. Two different delays were recorded during time study, an operational and a technical delay. Operational delays were recorded in loading area and unloading area due to operator and workers and technical delay occu-

Table 2. Summary of time variables for Urus MIII skyline yarder Tablica 2. Sažeti prikaz vremenskih varijabli za žičaru Urus MIII

\begin{tabular}{|c|c|c|c|c|}
\hline $\begin{array}{l}\text { Factors } \\
\text { Čimbenici }\end{array}$ & 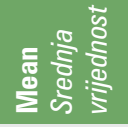 & 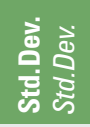 & 肓菨 & 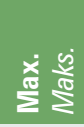 \\
\hline Travel of unloaded carriage (min.) & 0.36 & 0.22 & 0.2 & 1.05 \\
\hline Vožnja neopterećenih kolica & & & & \\
\hline $\begin{array}{l}\text { Hooking of load (min.) } \\
\text { Vezanje tovara }\end{array}$ & 2.07 & 0.46 & 1.01 & 3.00 \\
\hline $\begin{array}{l}\text { Travel of loaded carriage (min.) } \\
\text { Vožnja opterećenih kolica }\end{array}$ & 2.23 & 0.54 & 1.38 & 3.35 \\
\hline $\begin{array}{l}\text { Unhooking of load (min.) } \\
\text { Odvezivanje tovara }\end{array}$ & 0.41 & 0.14 & 0.20 & 1.00 \\
\hline $\begin{array}{l}\text { Delay time (min.) } \\
\text { Prekidi }\end{array}$ & 0.56 & 0.60 & 0.11 & 2.2 \\
\hline $\begin{array}{l}\text { Total time (without delay) (min.) } \\
\text { Ukupno vrijeme (bez prekida) }\end{array}$ & 5.47 & 0.95 & 4.28 & 7.5 \\
\hline $\begin{array}{l}\text { Total time (with delay) (min.) } \\
\text { Ukupno vrijeme (s prekidima) }\end{array}$ & 6.43 & 1.09 & 4.28 & 8.1 \\
\hline $\begin{array}{l}\text { Yarding distance }(\mathrm{m}) \\
\text { Duljina žičare }\end{array}$ & 252.767 & 41.73 & 185 & 320 \\
\hline $\begin{array}{l}\text { Load volume }\left(\mathrm{m}^{3}\right) \\
\text { Obujam tovara }\end{array}$ & 1.187 & 0.36 & 0.54 & 1.890 \\
\hline $\begin{array}{l}\text { Number of timber }(\mathrm{n}) \\
\text { Broj komada drva }\end{array}$ & 1.86 & 0.68 & 1 & 3 \\
\hline $\begin{array}{l}\text { Lateral dragging }(\mathrm{m}) \\
\text { Postrano izvlačenje užeta }\end{array}$ & .87 & 4.35 & 5 & 23 \\
\hline
\end{tabular}


rred due to breakdowns on truck and carriage. Timber recorded data include diameter and log length.Variables consist of load volume $\left(\mathrm{m}^{3}\right)$, yarding distance $(\mathrm{m})$, lateral dragging $(\mathrm{m})$ and number of logs per load. In this time measurement study, 30 work cycles were recorded for Urus MIII skyline yarder in given stand and terrain conditions.

\section{RESULTS}

REZULTATI

In this study, SPSS 21.0 statistical programmer has been applied for developing regression equation of time measurements (Anonymous 2012). Regression analysis has been realized with ENTER method. Summary for the total yarding cycles can be found in Table 2 .

A linear regression was developed from the time study using Urus MIII skyline yarder with total 30 yarding cycle. This regression model was as follow;

$$
\mathrm{T}=-0,832+0,024 \times \mathrm{YD}+0,480 \times \mathrm{V}+0,025 \times \mathrm{LD}
$$

where;

$$
\begin{gathered}
\mathrm{T}=\text { Yarding time with delays }(\mathrm{min} / \mathrm{cycle}) \\
\mathrm{YD}=\text { Yarding Distance }(\mathrm{m}) \\
\mathrm{V}=\text { Volume }\left(\mathrm{m}^{3}\right) \\
\mathrm{LD}=\text { Lateral Dragging }(\mathrm{m})
\end{gathered}
$$

Yarding distance, load volume and lateral dragging per cycle were at significant level of 0.05 . The multiple correlation coefficients $(\mathrm{R})$ are interpreted as $83 \%$ of total variability. Autocorrelation was determined with Durbin

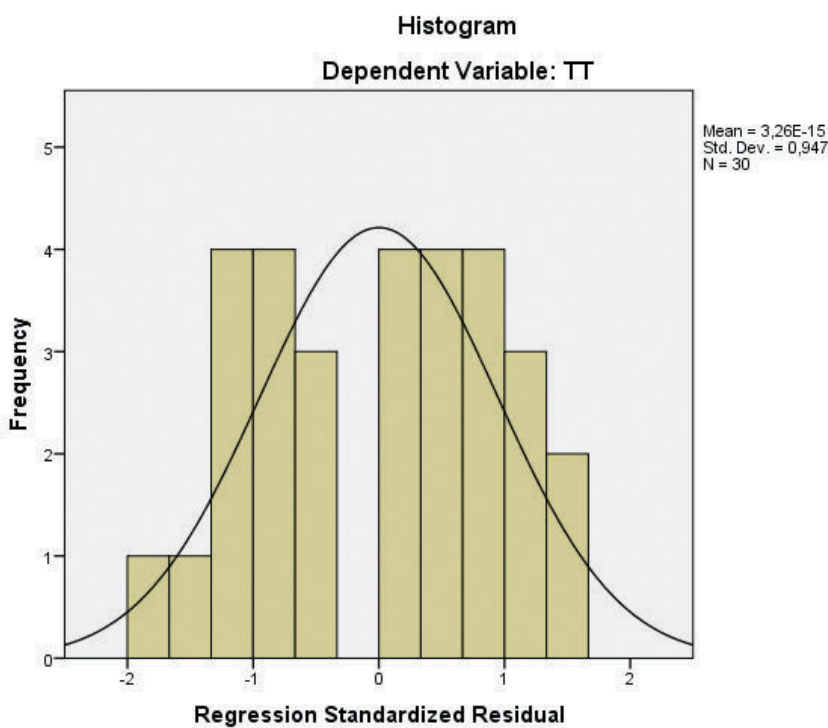

Figure 3. Histogram of standardized residuals of the overall time consumption model in yarding

Slika 3. Histogram standardiziranih ostataka cjelokupnog modela utroška vremena pri iznošenju drva žičarom

Watson test, which indicated a positive autocorrelation (Table 3 and 4 ). The histogram of standardized residuals is shown in Figure 3.

The average total cycle time was 6.43 minute for average length of 253 meters. The hourly production with delay times for Urus MIII skyline yarder was $10.60 \mathrm{~m}^{3}$ for this

\begin{tabular}{|c|c|c|c|c|c|c|}
\hline \multirow{2}{*}{ Model } & \multicolumn{2}{|c|}{$\begin{array}{l}\text { Unstandardized Coefficients } \\
\text { Nestandardizirani koeficijenti }\end{array}$} & \multirow{2}{*}{$\mathrm{t}$} & \multirow{2}{*}{ Sig. } & \multicolumn{2}{|c|}{$\begin{array}{l}\text { Collinearity Statistics } \\
\text { Kolinearna statistika }\end{array}$} \\
\hline & B & $\begin{array}{l}\text { Std. Error } \\
\text { Std. greška }\end{array}$ & & & $\begin{array}{l}\text { Tolerance } \\
\text { Toleranca }\end{array}$ & VIF \\
\hline (Constant) - (Konstanta) & $-0,832$ & 0,776 & $-1,073$ & 0,293 & & \\
\hline Distance - Udaljenost & 0,024 & 0,003 & 9,384 & 0,000 & 0,702 & 1,424 \\
\hline Lateral dragging - Postrano izvlačenje užeta & 0,480 & 0,273 & 1,756 & 0,091 & 0,826 & 1,211 \\
\hline Load Volume - Obujam tovara & 0,025 & 0,022 & 1,128 & 0,270 & 0,832 & 1,201 \\
\hline
\end{tabular}
distance. The daily production was $84.80 \mathrm{~m}^{3}$. Yarder production without delay times was $12.31 \mathrm{~m}^{3} /$ hour. Two most

Table 3. Statistical characteristics of models based on regression analysis Tablica 3. Statističke karakteristike modela temeljene na regresijskoj analizi

Table 4. Values of models based on regression analysis

Tablica 4. Vrijednosti modela temeljene na regresijskoj analizi

$\begin{array}{lccc}\begin{array}{l}\text { Adjusted R Square } \\ \text { Prilagođeni } R^{2}\end{array} & \begin{array}{c}\text { Std.Error of the estimate } \\ \text { Std. greška procjene }\end{array} & \text { Durbin Watson } \\ 0,807 & 0,47764 & 41,356 & 1,836\end{array}$

Table 5. Total yarding cycle determined from the detail time study

Tablica 5. Ukupni ciklus izvlačenja po žičari određen prema detaljnoj studiji vremena

$\begin{array}{lcccccc}\begin{array}{l}\text { Time } \\ \text { Vrijeme }\end{array} & \begin{array}{c}\text { Travel unloaded of carriage } \\ \text { Vožnja neopterećenih kolica }\end{array} & \begin{array}{c}\text { Hookup of load } \\ \text { Vezanje tovara }\end{array} & \begin{array}{c}\text { Travel loaded of carriage } \\ \text { Vožnja opterećenih kolica }\end{array} & \begin{array}{c}\text { Unhook of load } \\ \text { Odveivzanje tovara }\end{array} & \begin{array}{c}\text { Delay } \\ \text { Prekidi }\end{array} & \begin{array}{c}\text { Total Time } \\ \text { Ukupno vrijeme }\end{array} \\ \text { Minute } & 0.36 & 2.07 & 2.23 & 0.41 & 0.56 & 6.43 \\ \text { Percent - Postotak } & 8.9 & 31.5 & 35.5 & 10.2 & 13.9 & 100\end{array}$


Table 6. Detailed costs of skyline yarder Tablica 6. Detaljni troškovi žičare

\begin{tabular}{lc}
\multicolumn{1}{c}{\begin{tabular}{c}
\multicolumn{1}{c}{ Parameters } \\
Parametri
\end{tabular}} & $\begin{array}{c}\text { Cost }(€) \\
\text { Troškovi }\end{array}$ \\
$\begin{array}{l}\text { Fixed costs - Fiksni troškovi } \\
\text { Deprecition - Deprecijacija } \\
\text { Interest - Kamate } \\
\text { Insurance and Taxes } \\
\text { Osiguranje i porez }\end{array}$ & 1,74 \\
Operating costs & 1,91 \\
Operativni troškovi & 0,52 \\
Repair and Maintenance & \\
$\begin{array}{l}\text { Popravci i održavanje } \\
\text { Fuel and Lubrication } \\
\text { Gorivo i mazivo } \\
\text { Cable } \\
\text { Užad } \\
\text { Mounting and dismantling } \\
\text { Montaža i demontaža }\end{array}$ & 4,17 \\
\hline $\begin{array}{l}\text { Operating cost } \\
\text { Operativni troškovi } \\
\text { Labor - Rad }\end{array}$ & \\
Total cost - Ukupni troškovi & 6,87 \\
\hline
\end{tabular}

time consuming components of total yarding time were load hookup and travel of loaded carriage. Delays were $13.9 \%$ of the total yarding cycle time; and ranged from $87 \%$ in operational delays to $13 \%$ in technical delays. Table 5 shows detail time study for total yarding cycle.

The operation cost of the Urus MIII skyline yarder was based on fixed and variable costs. Fixed costs include: the cost of interests, depreciation, tax and insurance. Depreciation was calculated according to economic lifetime of 10 years. The fuel consumption of Urus MIII skyline yarder was $5 \mathrm{l} / \mathrm{hr}$ and it was measured during timber extraction operations. Lubricant costs were assumed to be $23 \%$ of total fuel cost (Ozturk, 2004). Total cost of Urus MIII skyline yarder was $30.00 € / \mathrm{hr}$. Detailed costs of skyline yarder are shown in Table 6.

In this study, the most time during skyline yarder operations has been spent for travel of loaded carriage phase

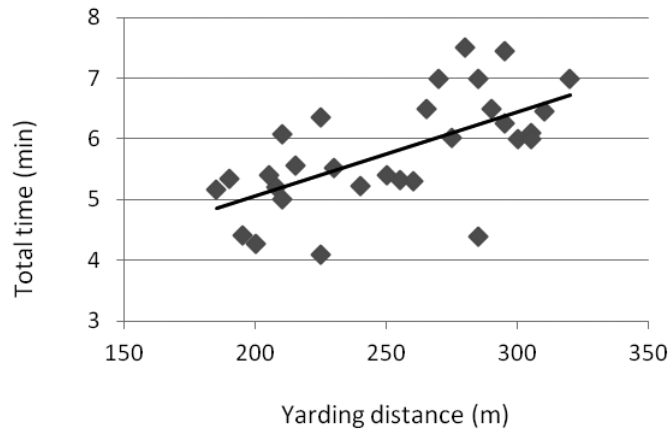

Figure 4. Relationship of yarding distance and total time Slika 4. Odnos duljine žičare i ukupnog vremena

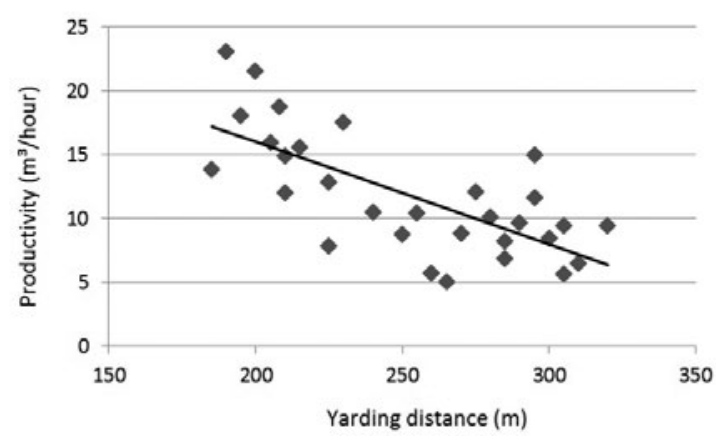

Figure 5. Relationship of yarding distance and productivity Slika 5. Odnos duljine žičare i produktivnosti

(35.5\% of total time). Total yarding time increased as the yarding distance increased. The average delay free time consumption of yarding was approximately 13.9\% lower than the time consumption with delays. The average number of timber per load was 2, approximately, the average yarding distance was $253 \mathrm{~m}$ and the average volume per a cycle was $1.187 \mathrm{~m}^{3}$. By increasing yarding distance, productivity of Urus MIII skyline yarder and total time of a cycle time decreased. An inverse relationship of productivity with yarding distance and a direct relation with volume transported are visible in figures 4 and 5 .

\section{CONCLUSION AND DISCUSSION ZAKLJUČAK I DISKUSIJA}

This paper shows the results of research of yarding timber by Urus MIII yarder. The average total time consumption with delay time per cycle was $6.43 \mathrm{~min}$. The average lost time per cycle was $0.52 \mathrm{~min}$. The average load volume was $1.187 \mathrm{~m}^{3} /$ cycle and load averagely consisted of 2 pieces. In this study, the productivity of Urus MIII skyline yarder was $10.60 \mathrm{~m}^{3}$ /hour and daily productivity of yarder was 84.80 $\mathrm{m}^{3}$. Aykut et al. (1997) reported that productivity of Urus MIII skyline yarder was $8.60 \mathrm{~m}^{3} /$ hour for 240 meters of line length and Caglar et al. (2003) found it to be $3.80 \mathrm{~m}^{3} /$ hour for $600 \mathrm{~m}$ line length. Ozturk (2004) reported that productivity of Urus MIII skyline yarder is $12.90 \mathrm{~m}^{3} /$ hour for 350 meters of line length. This study when compared to previous ones shows higher productivity of the yarder. In this harvesting area, the shrubs and ground cover wasn't dense and the workers were able to move much easily in the area. In this study, the average fuel consumption was 5 liters. In this study, the costs of the Urus MIII skyline yarder were $30.00 € /$ hour and $2.83 € / \mathrm{m}^{3}$, respectively. Ozturk (2004) mentioned that the cost of Urus MIII skyline yarder was $5.24 \$ / \mathrm{m}^{3}$. The average speed of unloaded carriage (downhill) was $70 \mathrm{~m} / \mathrm{min}$ and the average speed of loaded carriage (uphill) was $184 \mathrm{~m} / \mathrm{min}$.

In this study, the cleared corridor for skyline yarder operation was 2.5 meters and the width of this corridor was eno- 
ugh for all yarding operations. Melemez (2014) mentioned that if the corridors are narrower than $5 \mathrm{~m}$, carriage may damage nearby standing trees.

In this study, the mounting time of the skyline yarder was 6 hours, while the dismantling time was 4 hours. Mounting operations are dependent on workers experience, terrain conditions (slope, ground bearing capacity, ground roughness) as well as vegetation density. Stampfer et al. (2006) reported that while an uphill short corridor $(150 \mathrm{~m})$ can be installed on average in 6 hours; a $500 \mathrm{~m}$ downhill corridor with a single support will require 23 hours. In this study, the mounting time has taken less time for $400 \mathrm{~m}$ installation distance. Mounting and dismantling times affect the work productivity for cable systems (Zimbalatti and Proto, 2009).

While the harvesting areas where timber yarding is performed by skyline yarder, after determining its route and mounting the skyline line, processed timber are transported toward the cleared corridor by human force with assist of gravity. Thus, lateral dragging distance is shortened and the required time and worker force is also decreased to some extent. In this study, the average lateral dragging was found to be 13.9 meters. Productivity of cable systems is highly affected by dense ground vegetation, delay time in loaded area will decrease; and the hourly production of the skyline yarder will increase significantly (Ozturk, 2004). It should be mentioned that operator and workers should be kept subject to a well training and they should have a certificate.

\section{REFERENCES}

\section{LITERATURA}

- Anonymous, 2012. IBM SPSS Advanced Statistics 21(Installation Cd rom).

- Aykut, T., H.H. Acar, N. Senturk, 1997: An investigation on the comparison of Koller K300, URUS MIII and Gantner skylines used for extraction from compartment in Artvin region. I.U.Review of the Faculty of Forestry, University of Istanbul, 47 (A2): 30-58.

- Caglar, S., A. Karaman, H.H. Acar, 2003: An Investigation on logging by Baco and Gantner skylines. XXXI. International Forestry Students (IFSS) Symposium, 1st-15th September 2003, Proceedings of Symposium, pp.106-113, Istanbul / Turkey.
- Cavalli, R., S. Grigolato, 2010: Influence of characteristics and extension of a forest road network on the supply cost of forest woodchips. J.Forest Res. 15: 202-209.

- Enache, A., P.Tibor, V.D. Ciobanu, K.Stampfer, 2015: GIS based methods fpr computing the mean extraction distance and its correction factors in Romanian mountain forests. Sumarski Lİst, 1-2: 35-46.

- Eroglu, H., M.S.Ozkaya, H.H.Acar, A.Karaman, A.Yolasigmaz, 2009: An investigation on roundwood extraction of Fagus orientalis lipsky, Abies nordmanniana (Stew.) Spach. and Picea orientalis (L.) Link. by Urus MIII forest skyline on snow. African Journal of Biotechnology, 8(6): 1082-1089.

- Hoesch, M., 2003: Technology development as driving force for rationalization in forest companies. Austro2003: High Tech Forest Operations for Mountainous Terrain, October 5-9, Schlaegl - Austria.

- Huber, C., K.Stampfer, 2015: Efficiency of topping trees in cable yarding operations. Croat. J. for Eng. 36(2): 185-193.

- McDonald, T.P., J.P.Fulton, 2005: Automated time study of skidders using global positioning system data. Computers and Electronics in Agriculture, 48: 19-37.

- Melemez, K., M.Tunay, 2014: A comparison of productivity in five small-scale harvesting systems. Small-Scale Forestry, 13: 35-45.

- Ozturk, T., 2004: The research on transporting forest products with varied forest skylines in mountainous forest zone of Turkey. Istanbul University, Journal of the Faculty of Forestry, A 54 (1): 65-85.

- Ozturk, T., N.Senturk, 2006: Extraction of spruce timber by Gantner cable crane from selective forests of artvin region. Croatian Journal of Forest Engineering, 27(1): 59-65.

- Stampfer, K., R.Visser, C.Kanzian, 2006: Cable corridor installation times for European yarders. International Journal of Forest Engineering, 17(2):71-77.

- Proto, A.R., G.Zimbalatti, 2015: Firewood cable extraction in the southern Mediterranean area of Italy. Forest Science and Technology, 1-8.

- Visser, R.J.M., K.Stampher, 1998: Cable extraction of harvester felled thinnings an Austrian case study. J.For. Engineering, 1: 39-46.

- Wang, J., J.McNeel, J.Baumgras, 2003: A computer-based time study system for timber harvesting operations. Forest Products Journal, 53(3): 47-53.

- Zimbalatti, G., A.R.Proto, 2009: Cable logging opportunities for firewood in Calabrian forests. Biosystems Engineering, 102: 63-68.

- Zimbalatti, G., A.R.Proto, 2010: Timber extraction with a cable crane in south Italy (Calabria). FORMEC 2010. Forest Engineering: Meeting the Needs of the Society and the Environment, Padova, Italy.

\section{Sažetak}

Cilj je ovog rada istražiti produktivnost i troškove žičare Urus MIII tijekom iznošenja drva iz sastojina smreke u sjeveroistočnoj Turskoj. Produktivnost žičare Urus MIII određena je uporabom povratne metode studija rada i vremena. Rezultati istraživanja ukazuju da neke radne karakteristike žičare Urus MIII, kao što su potrošnja goriva, obujam tovara, udaljenost iznošenja, brzina iznošenja i utrošeno vrijeme po ciklusu, imaju važan učinak na produktivnost žičare. Dobiveni rezultati pokazuju da je produktivnost žičare Urus MIII iznosila $10,63 \mathrm{~m}^{3} / \mathrm{h}$ za srednju udaljenost iznošenja drva od $253 \mathrm{~m}$. Dnevna produktivnost bila je $84,80 \mathrm{~m}^{3}$. Jedinični trošak rada žičare iznosi $30.00 € / h$. Također, prosječna potrošnja goriva iznosila je 5 litara/h. 